DOI: $10.2478 / \mathrm{v} 10122-012-0010-4$

\title{
DIFFERENCES IN THE LEVEL OF LITERACY BETWEEN MINOAN AND MYCENAEAN SOCIETIES IN THE LIGHT OF THE ANALYSIS OF TYPES AND PROBABLE USE OF INSCRIBED OBJECTS
}

\author{
MALGORZATA ZADKA
}

\begin{abstract}
Małgorzata Zadka. Differences in the Level of Literacy between Minoan and Mycenaean Societies in the Light of the Analysis of Types and Probable use of Inscribed Objects. Lingua Posnaniensis, vol. LIV (1)/2012. The Poznan Society for the Advancement of the Arts and Sciences. PL ISSN 0079-4740, ISBN 978-83-7654-103-7, pp. 133-138.

The aim of this paper is to present the suspected differences in the level of literacy between Minoan and Mycenian populations. Through the analysis of the number and type of preserved objects, which were inscribed in Linear A and comparing the results with the type of artefacts inscribed in Linear B we are able to define the original function of script in both cultures. The preserved epigraphic and archaeological material may indicate that the writing skills were more prevalent in the earlier Minoan than in the Mycenaean era.
\end{abstract}

Małgorzata Zadka, Institute of Classical, Mediterranean and Oriental Studies, University of Wrocław, Szewska 49, PL - 50-139 Wrocław, malgorzata.zadka@gmail.com

A script called Linear B, used on Crete and on the Greek continent in Late Bronze Age, is the oldest notation of Greek language that we know. The language is however, in many aspects, completely different to the one which survived in later alphabet inscriptions. Also, the way of notation itself illustrated language in much different way than alphabet, because the script was syllabic and each symbol corresponded only to an open syllable. Because Greek language is of no-syllabic structure, it caused some distortions and inaccuracy in notation. The script however (likewise other aspects of material culture such as painting, ceramics, ornaments) was not created by the Hellenes themselves but was adopted from the Minoans and adjusted to the needs of Greek language. Basing on the remaining archeological material, we can observe similarities between these cultures also in the scope of art, religion and (probably) administration; but still the issue of universality of use of writing has not been examined well for both of them. In spite of the fact that only a small part of written documents is available to us (these which managed to survive in rather humid climate of Greece ${ }^{1}$ ) one can observe some differences in the use of writing in both of these societies. Societies,

1 Inscriptions have been preserved primarily on hard materials such as stone, burnt clay and metal. There are some indications that perhaps also written on skins or papyrus, researchers are not unanimous on this issue because of the lack of direct evidence. 
and that should be stressed, which were functioning in the same place, in similar conditions and in undoubted contact with each other.

The significant variety characterizes Linear A documents. They have been preserved on small clay objects (so-called cretualae), tablets, inscribed ostraca (fragments of pottery), gold and silver pins, miniature double axes, libation stoneware. Their provenience is also various: they have been found in Minoan palace and sacrificial centers, villas and smaller settlements (e.g. privat houses). The artefacts have been found on Crete and surrounding islands, continental Greece, coasts of Minor Asia and Levant. Undoubtedly, the use of these objects was also diverse. Tablets and cretualae are regarded to be the elements of administration system; but the connection between these two types of notation has not yet been established. The Minoan tablets we posses are relatively small, and therefore they could not have contained as many information as bigger Linear B tablets. Linear A inscriptions on libation tables and other objects with cultic destination are probably votive texts. The texts seem to have formulaic forms (Michailidou 2000-2001: 17) and they cannot be of the same character as the texts inscribed on other objects (e.g. libation tables). There is therefore no sense in comparing religious texts and economic accounts.

Diversity of the preserved objects and the big variety of their appications rises a question about the level of literacy in Minoan society. Inventory records allow us to assume the existence of a group of specialized scribes while inscriptions on the ostraca and metal objects (as they are mostly economic and votive records) can suggest that also private people were able to write simple texts. Perhaps the inscriptions found in private buildings had been used for household arithmetic (SсHOEP 1999: 205-206). Writing seems to be present in craftsman's spheres; but it is hard to determine if craftsmen were hiring scribes or wrote themselves. Also, it is impossible to answer the question about the actual time of carving the Linear A symbols on clay vessels, if they were carved before the firing, probably by the person who created them, or after the firing (in this case they had been produced for a private individuals for personal use or for qualified specialists). We also do not know if the inscriptions on libation tables or mugs from Knossos (Evans 1921: 623n) were created by a scribe, priest or by the owner of the mug himself. Known inscriptions of monumental character - the inscription on a wall painting in Knossos (symbol AB 50) (CAMERON 1965: 12-15) and symbols impressed in a plaster in Haghia Triada (Evans 1921: 637), do not give us the information by whom and in what purpose they were created. Researcher Anna Michailidou thinks that inscriptions on libation tables and other objects of this type were indecipherable for majority of the Crete population. However, they could understand computational inscriptions such as numbers and ideograms, and sometimes they curved a property sign on a mug or other object (MichaiLidou 2000-2001: 25). It is also unclear if we can talk about professional scribes in the Minoan period on Crete. In Egypt and Sumer this post was important and valued, and a was a vital element of the state administration (MicHAiLIDOU 2000-2001: 20). In Egypt scribes were not only at pharaoh or temple service but they were hired also by private individuals, mayne in the similar way the post was organized in the Minoan society (we have a linear A inscriptions from a private settlement in Akrotiri). 
The majority of the linear B inscriptions has been preserved on clay tablets containing lists of people, animals, plants and objects used in palace system of goods redistribution, incomes and expenditures controlling. In much smaller extent inscriptions have been preserved on clay objects of different shape and ceramics. Part of the findings are small clay objects, generally called as labels or cretulae because they were probably used to seal documents, vessels, baskets and other objects which contents were destined to specified addressees and simultaneously protect them from misuse. Almost every Linear B inscriptions were found in the palaces, mostly in separate rooms, recognized by archeologists to be archives. Additional proof of using the writing closely connected to palaces, is the lack of records dated to the period after their damage in PH III B - PH III C (after 1200 BC) (PALAIMA 1987: 499). Cretulae constitute only about $3 \%$ of the inscribed objects, the same ratio is for other types of small objects (different then tablets).

Linear B inscriptions have been preserved on objects of more homogeneous character than Linear A. On tablets which contain lists, the symbols are neat and placed between signed lines. This fact, likewise concentration of the records in the archives of the palatial centers, inclines to treat them as a result of work of professional scribes. Linear B writing was also characterized by substantial standardization: despite of the fact that the script was used in different centres and during few hundreds of years (DuHoux 2007: 1). Basing on characterological analysis of the writing it is being assumed that tablets from Knossos were written by about 60-110 individuals, from Pylos by 33-45, from Mycenae by 14 (PaLAimA 1987: 504).

That big number of scribes from Knossos might suggest that in fact every official was able to write. It would confirm the fact that individual characters of writting are connected with different fields of the economy. This seems to indicate that instead of hiring professional scribes to work in the palaces, individual officials were obliged to have writing skills (LEWARTOWSKi 2001). There are no proofs for "low" literacy ${ }^{2}$ in Mycenaean society (although only private records on ostraca, vessels, votive offerings, tracks of untrained hands on inscriptions, sanctuaries and private houses have been preserved). We are facing also a problem of the lack of styluses, inkwells and inscriptions on monuments. ${ }^{3}$ Symbols impressed on vessels are not numerous. Probably Linear B script was not adjusted to express one's thoughts freely and was not good enough for recording poetry or historiography, contrary to accounting of incomes and expenditures. One can have doubts because of completely different use of the Cypriot Sylabary, related to the Linear B script, which has very similar structure and was used to write on ceramics, votive offerings and epitaphs. We will find it on graffiti of Cypriot traders in Egypt, on vases inscriptions, royal marble inscriptions and on over 100 of notices on ceramics from Nymphaion near Idalion (225-118 BC) (Palaima 1987: 505). Moreover, research on handwriting revealed multiplicity of "hands" that took part in recording of Cypriot inscriptions. Another problem of vital importance is

2 Palaima separates "high" literacy characterized by the existence literary, religious, historical records, codified laws and liturgical texts, from "law" literacy, testified by the private inscriptions on ostraca, vessels, in houses and sanctuaries. This issues were also discussed by Dow and Chadwick.

3 On the other hand, no writing tools were found also among the Minoan, Cypro-Minoan and Middle Eastern finds. 
that Cypriot Sylabary was functioning even in the time when Greek alphabet was in common use and the sylabary should have been replaced much faster by the alphabet as it was impractical and distorting.

Non-adaptation of the Linear B script to Greek notation was pointed also by DuHoux (2000: 37-57), FACChetTI (2002: 141-147), JASINK (2006: 39) and SHARYPKIN (2010: 218) who emphasized the fact that it was used only by qualified group of scribes. They could write both for themselves and for higher- or lower-rank officials (SHARYPKIN 2010: 222). Duhoux suggested that scribes were using very archaic type of language that sounded different while speaking. However, the fact that officials from different centres were using their own graphic solutions for words that sound the same (i.e. pe-te-re-wa next to pte-re-wat) (DuHoux 2007: 15) might suggest that each of the scribes wrote in the scope of some freedom and own invention, without taking care of widely-held schemes and formulas.

Researchers emphasize the fact that the language of Linear B notations was not identical to the one used for oral communication and was used only for administrative purposes (Adrados 2005: 29; Duhoux 2000: 37-57; SharYPKIN 2002: 32).

Maybe in the Mycenaean age there was no need to record anything else than administrative documents because literary works existed as oral tradition. Despite the lack of any, possible to identify, remains of Mycenaean literature (HACKSTEIN 2010: 403), there are "story singers" shown on frescos from Pylos and ru-ra-ta-e (linked with Greek *lyrastes 'lyrist') TH Av 106,6 are recalled on the tablets from Thebes (MeIER-BRÜGGER 2003: 233; WEST 1988: 165).

The research on literacy are difficult because of the shortage of knowledge on the actual ratio of preserved texts in comparison with the number of originally written ones. Due to this situation, some risk of inadequate conclusions, regarding the level of literacy and based on partly preserved material, exists. However, the analysis of the frequency of the preserved artefacts and research of other ways of determining so-called "high" or "low" literacy, might show some regularities. Lack of preserved styluses and other writing tools as well as public, monumental inscriptions in stone (permanent material) may reflect the limited Linear B literacy. While in Mesopotamia and Egypt thousands of shells which served students of scribe schools were found, there are no finds of this type form Mycenaean archeological sites. There are also no graphic depictions of writing materials which would be analogical to numerous Egyptian and Assyrian notions of scribes, writers and also to later depictions of Greek teachers or other people with scrolls or tablets in one hand and styluses in other. Preserved texts characterize unique coherence of graphic styles, orthography and shapes of tablets in different centres. The number of so-called "hands", which means a number of individual handwritings, indicates limited group of people who created the records. All these facts could prove the existence of a narrow group of officials who were able to write and who were creating texts in the scope of organized and unified system. Furthermore, we do not know any writing remainings created after damaging the palatial centres in $1200 \mathrm{BC}$.

4 First quoted word comes from KN So 984.1, second from: KN Se 879.b; 891.B; 829; 893; 5729; So 4429.b; 4431; 4437; 4440.b; 4445; 4448 and 4449. 
If writing was spread, independent of palace administration private records should have come into being. Provided that "high" literacy of a society shows the existence of historical literature records, poetry, liturgy and a code of laws; it is interesting that there are no authenticated signs of Linear B script for so-called "low" literacy such as private records craped on parts of vessels, graffiti on offices. Only about $0,2 \%$ of all texts are considered to be this kind of inscriptions. In case of LA script it is about 3\% of all inscriptions in much more varied contexts.

LB script was so poorly adjusted to Greek language notation that some of the ancient historians (Duhoux, Facchetti, Sharypkin) are prone to consider it as a kind of administrative shorthand writing - useful while writing down official records but inadequate to write down literature and private texts.

One can have the impression that the skill of writing was more common in the Minoan age than in the Mycenaean. Paradoxically the range of literacy has decreased and had reduced with the passing of time. Some of the Minoan records indicate a private character and (despite it is difficult to assess the scale and level of advancement of this skill completely) could have been made by individual tradesmen or farmers without the necessity to use services of a scribe. The use of Linear A script seems to be less centralized than Linear B which obviously makes up with palace administration. Linear A inscriptions are also internally more irregular than elegant and organized Linear B.

A lot of things indicate that in the Minoan age the writing skill was available to some extent rather universally; while the Hellenes used it in more decreased degree. It could have proven bigger polarization of their society, in which the contrast between illiterate farmers, craftsmen and educated officials, functioning as a part of palace administration, was remarkable. The Hellenes could have been on lower level of society development than users of Linear A script. However, research on this sphere of life still have not brought final solution.

Writing is a material expression of a language, a mean of communication in a society that aspires to record information that do not function in the scope of oral tradition - administrative and economic records, calculations and registers. It could also serve for private records, notes, point one's ownership. The example of different ways of using script in the Minoan and Mycenaean society shows how different can be the needs for using this kind of technology such as writing, depending on the level of development or the values vital for each society. One can see here, that often the societies which function close to each other and draw from their stores of culture can use their elements in different spheres or in different dimensions: communicating with each other by using a very similar medium but in a complete different way.

\section{REFERENCES}

Adrados Francisco Rodriguez. 2005. A History of the Greek Language from Its Origins to the Present. LeydeBoston: Brill.

BAKKer Egbert J. (ed.). 2010. A Companion to the Ancient Greek Language. Chichester-Malden, MA: Blackwell Publishing. 
Cameron Mark A.S. 1965. "Four Fragments of Wall Paintings with Linear A Inscriptions." Kadmos 4, 12-15.

Duнoux Yves. 2000. "Le linéaire B: une sténographie de l'âge du Bronze." Živa Antika 50, 37-57.

Duhoux Yves. 2007. "Le linéaire B note-t-il une language Vivanie ou figée? Les leçons de Cnossos." L'Antiquité Classique 76, 1-23.

Evans Arthur. 1921. The Palace of Minos. London: MacMillan and Co.

FACCHETti Giulio. 2002. "La lineare B: una scrittura contabile e largamente imperfetta." Kadmos 41, 141-147.

Godlewski Grzegorz (ed.) 2007. Communicare. Almanach antropologiczny. Oralność/Piśmienność (Communicare. Antropological Almanac. Orality/Literacy). Warszawa: Wydawnictwa Uniwersytetu Warszawskiego.

Goody Jack, WATT Ian. 2007. "Następstwa piśmienności.” (Consequences of literacy). In: GoDLEwSKI 2007: 3373.

HACKSTEIN Olav. 2010. “The Greek of Epic.” In: BAKKer 2010: 401-423.

JASINK A. Margherita. 2006. "Mycenaean Fiscal Vocabulary: Oral or Written Tradition?” In: Perna 2006: 39-47.

LEWARTOWSKI Kazimierz. 2001. Archeologia egejska (Aegean Archeology), http://www.archeo.uw.edu.pl/podrecznikegea/generator.php?plik=pisma\&tytul=Pisma [23.01.2011].

Meier-BrügGer Michael. 2003. "Die homerische Kunstsprache.” In: Ulf 2003: 232-244.

Michailidou Anna. 2000-2001. "Indications of Literacy in Bronze Age Thera." Minos 35-36, 7-30.

Palaima Thomas. 1987. "Comments on Mycenaean Literacy." Studies in Mycenaean and Classical Greek presented to John Chadwick, Salamanca 1987 (=Minos 20-22), 499-510.

Perna Massimo (ed.). 2006. Fiscality in Mycenaean and Near Eastern Archives. Napoli: DeBoccard.

Schoep Ilse. 1999. "Tablets and Territories? Reconstructing Late Minoan IB Political Geography through Undeciphered Documents." AJA 1999, 201-221.

SHARYPKIN Serguey. 2002. "Jeszcze raz o charakterze pisma linearnego B" (Once again about the nature of the Linear B script). Collectanea Philologica IV Ignatio Richardo Danka sexagenario oblate. Łódź: Wydawnictwo UŁ, 31-45.

SHARYPKIN Serguey. 2010. “Alcune rifflesioni sull'adeguatezza di una scrittura largamente disadeguata.” Pasiphae III, 215-224.

Ulf Christoph (ed.). 2003. Der neue Streit um Troia. Eine Bilanz. Munich: C.H. Beck Verlag.

WeSt Martin. 1988. "The Rise of the Greek Epic". JHS 108, 151-172.

Allatum die 28 mensis Januarii anno 2012 